\title{
3D Modeling of the Arab Formation (Maydan Mahzam Field, Offshore Qatar): An Integrated Approach

\author{
Ahmed Al-Emadi ${ }^{1}$, Stéphan J. Jorry ${ }^{2}$, Jean-Marc Chautru², Bruno Caline ${ }^{3}$, Marie-Stéphanie Blum², Nizar
} Jeddaan ${ }^{1}$, Vance Fryer $^{1}$, Patrick Léandri ${ }^{2}$, Christian Fraisse ${ }^{3}$ / 1-Qatar Petroleum, 2-Beicip-Franlab, 3-TOTAL
}

\begin{abstract}
The Late Jurassic Arab Formation consists of complex carbonate and evaporite facies associations deposited along ramps and intra-shelf Arabian basins, which form large hydrocarbon fields. Most of the time, the 3D reservoir characterization of such reservoirs is challenging, due to superimposed diagenetic overprints. The aim of this paper is to present an integrated approach using original rock-typing and modeling methods for the characterization of the four main reservoirs of the Arab Formation in Maydan Mahzam Field (Qatar).

A sedimentological study was conducted on cores, and a sequence stratigraphy framework was developed. Three depositional models are proposed to illustrate the progradation of the Arab D carbonate platform toward the Southeast and the deposition of inner ramp/sabkha facies of the Arab A, Arab B and Arab C reservoirs. Rock-types that are characterized by specific geological, petrophysical and $\mathrm{Kr} / \mathrm{Pc}$ properties have been defined from cores and thin sections, taking into account log response and SCAL measurements. These rock-types have been extended to all the wells by mean of a semi-interactive statistical classification applied on log data. They have been propagated in a 3D grid using a non-stationary geostatistical approach guided by $3 \mathrm{D}$ probability cubes. The probability cubes calculation is based on local vertical proportion curves determined from well sets and from the sedimentological models which cover undrilled areas.
\end{abstract}

This paper contributes to a better understanding of the sedimentology of the Arab Formation in Qatar and helps to refine the regional distribution of the Arab D reservoir facies. It demonstrates that an accurate rock-typing scheme combined with the definition of a sequence stratigraphy framework are of prime importance for building 3D static models, which honor geological concepts for carbonate reservoir simulation. 


\section{1 - Introduction}

Maydan Mahzam is an offshore mature field located in the shallow water of the Arabian Gulf some 102 kilometers east of Doha, between the Halul Island and the marine boundary with Abu Dhabi (Figure 1). The Maydan Mahzam structure at Arab $\mathrm{C}$ and D levels consists of an elongated domal structure (measuring $9 \mathrm{~km}$ from North to South and $7.5 \mathrm{~km}$ from East to West), which is developed over a deep seated salt dome (Figure 1). The field was discovered in 1963 when commercial oil rates were tested from the Arab D reservoir. In subsequent appraisal wells it was found that the overlying Arab C formation also contained significant oil reserves.

In Maydan Mahzam, the main producing reservoir is the Kimmeridgian Arab D member, which lies above the Jubaila Formation. The reservoir comprises a complex assemblage of sedimentary facies dominated by coarse grainstones and rudstones, dolomites and muddy limestones, which were produced and deposited on the wide Kimmeridgian carbonate shelf including an adjacent intrashelf basin (Figure 1). Reservoir quality has a strong correlation to lithofacies with the coarse grainstones, rudstones and sucrosic dolomite, exhibiting the highest permeabilities. Porosity in the Arab D formation ranges from $3 \%$ to $36 \%$ and permeability reaches values up to 3.3 Darcies. The Arab D reservoir is capped by 40-45 feet of anhydrite, which represents a continuation of a major regression cycle and acts as a seal for the reservoir. The Arab A, B and C reservoir facies are composed of oolitic grainstones, lithoclastic and bioclastic rudstone, and microbial-dominated boundstones, capped by massive anhydrite layers. All these reservoir facies are mainly affected by dolomitization.

Regarding the sequence stratigraphy of Arab D reservoir, recent studies such as one published by Handford et al. (2002) indicate that three long term depositional sequences occurred, where the Lower Member of the Arab D reservoir corresponds to the uppermost regressive part of a third-order cycle that begins within the Jubaila/Diyab Formation.

\section{2 - Methodology}

The sedimentological study focuses on the description of 16 cores (Figure 1), representing a total length of 4000 feet. Petrographic texture, faunal content, dominant sedimentary structures and bioturbation traces, dissolution and dolomitization processes have been taken into account for the facies classification.

A petrographic study of 20 thin sections from 4 wells (MM11, MM-25, MM-29, MM-79) with petrographic and cathodoluminescence microscope was conducted in order to study the diagenesis of dolomitized layers of the Arab Formation and to understand the stratigraphic evolution of the dolomitization process. The samples were selected from the crest towards the southwestern flank of the Maydan Mahzam field, which include wells MM-29, MM-26, MM79, and MM11 (Figure 1). These samples have been exclusively selected from dolomitic intervals from the base of Arab DIIIB through the top of the Arab A reservoir. Microdrill sampling of diagenetic phases and stable isotope analysis $\left(\delta^{13} \mathrm{C}\right.$ and $\left.\delta^{18} \mathrm{O}\right)$ have been performed.

Depositional models were built by integrating results from both sedimentological core description and thin sections description that was performed for rock typing purpose. The classification and interpretation of the different depositional facies is done according to all sedimentary criteria: texture, grain and faunal content, sedimentary structures, position within stratigraphic sequences, etc.

The sequence stratigraphy analysis is based on the definition of small-scale cycles from core description, from which parasequences and depositional sequences have been deduced. Sequence boundaries and flooding- and maximum-flooding surfaces have been used to correlate parasequences and sequences between cored wells, and were propagated during a second step to the uncored wells.

The general workflow regarding the definition of rock types was defined in order to integrate geological data at different scales, including cores, thin section, sedimentological models, sequence stratigraphy and paleogeographic maps, logs, conventional core analysis (CCAL) and special core analysis (SCAL) measurements. This workflow is organized in four steps, as illustrated in Figure 2. For this study, the propagation of rock types was conducted by using a statistical clustering method.

A geological 3D grid was populated with static properties, i.e. rock types, porosity and permeability. For this purpose, local vertical proportion curves were calculated for all reservoirs from well groups defined on geographic criteria. In addition, dummy vertical proportion curves were generated for the propagation of rock types outside the zone controlled by wells, according to sedimentological and sequence stratigraphic rules. The next step consisted of the calculation of 3D blocks of proportion (considered as probability of presence) of each rock type by kriging from the vertical proportion curves. In

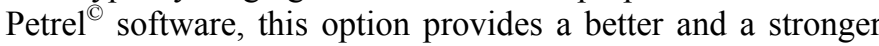
control on the result, and allows taking into account varying trends in a given lithostratigraphic unit. The rock types were distributed using the Sequential Indicator Simulation (SIS) method implemented in Petrel $^{\odot}$, constrained by the 3D blocks of proportion.

\section{3 - Results}

\section{1- Sedimentology and Diagenesis}

\subsection{1- Facies scheme}

In terms of facies classification, more than 50 lithofacies were defined. Facies, organisms, grains and burrows were organized along a synthetic 2D depositional bathymetric profile, having subdivided itself into three major depositional environments: the inner, middle, and outer ramp. 
The different facies defined from cores are the following:

A: Anhydrite. This is an evaporitic facies resulting from evaporation of intermittently flooded supratidal areas under arid climate. This facies mainly constitutes the massive anhydrite overlying the Arab D, C, B, and A reservoirs. However, it can be intercalated as thin beds within the Arab C, $\mathrm{B}$, and $\mathrm{A}$ reservoirs.

B: These are the Boundstone facies, where deposition results from in situ biological activity. Based on the relative abundance of a dominant component, different boundstone facies have been identified:

- BM: Algal/Microbial dominated. The laminae represent alternation of muddy and peloidal sediments. Sedimentary structures are represented by mud couplets, bird's eyes, mud cracks. Small perforating burrows are common. They contain no or very scarce fossils (mainly gastropods and ostracods). Porosity is mainly intercrystalline, with occasional small moldic and fenestrae voids. This facies often results from the dolomitization of algal mats deposited in extensive supratidal areas. It constitutes the major part of the upper part of the Arab D (i.e. interval I);

- BC: Cladocoropsis-dominated. No sedimentary structures (hydrodynamic and bioturbation) are observed. Porosity is mostly vuggy, moldic, and intercrystalline. This facies results from the growth of Cladocoropsis buildup on the foreshoal depositional environment. This facies is typically found above the transition between Arab DIII and DII;

- BS: Stromatolite-dominated. This facies results from the biological activity of stromatolites in supratidal to intertidal settings. Stromatolites are commonly thought to have been formed by the trapping, binding, and cementation of sedimentary grains by microorganisms, especially cyanobacteria (formerly known as blue-green algae). This facies mainly occurs at the top of shallowing-up cycles in the Arab C, B, and A reservoirs. This facies has not been observed in the Arab D reservoir.

$\mathrm{R}$ : These are very coarse limestones, classified as rudstones. They generally occur as massive beds (with few sedimentary structures, except for some planar or tabular cross bedding). Erosive bases and very coarse lag deposits are frequent. They are generally very poorly sorted, rich in intraclasts, compound grains and large stromatoporoid fragments (RC). The fossils are abundant and diversified: stromatoporoids, corals, bivalves, foraminifers, green algae. They are interpreted as being deposited in shallow water under very high energy conditions. Porosity is generally very high, mainly interparticle, intraparticle, moldic and vuggy. Grains are very much micritized, so that microporosity is also important. The thin section study allowed splitting this facies into two subfacies:

- $\quad$ RB rudstones are characterized by a high diversity of grains and fossils and are dominated by bioclasts such as bivalves and gastropods. These rudstones are developed in the Upper Arab D (interval DIIA and DIIB), and they probably represent more proximal high energy deposits, such as storm washover deposits or small tidal channels in the coastal area. These RB rudstones can sometimes be dolomitized in the upper part of high frequency depositional cycles.

- $\quad \mathrm{RC}$ rudstones are more intraclastic and show less fossil diversity, mainly dominated by Cladocoropsis fragments. The $\mathrm{RC}$ rudstones represent the uppermost deposits of an extensive shoal deposit (composed of many individual shoals) that separates an open marine domain from a more restricted lagoonal area. They also occur in the foreshoal environment where Cladocoropsis buildups are developed.

G: These are the grainstone facies. They are well to moderately sorted, medium to coarse grained, mostly composed of abundant peloids, ooids, and bioclasts. The bioclasts are rounded and diverse: compound grains, green algae, miliolids and other large benthic foraminifers, bivalves, echinoids, corals and stromatoporoid fragments. Bioturbation is rare, most of the time not observed, except for some Skolithos like burrows. Sedimentary structures are abundant: tabular laminations, planar and trough cross bedding. Some of them present an erosive base and a fining upward trend, and could therefore represent some tidal channel sands. But most of them occur as relatively thick coarsening upward units representing subtidal to intertidal shoals and offshore bars. In the Arab $\mathrm{C}$ reservoir, the intercalation of a $6 \mathrm{ft}$-thick interval composed of well sorted and fine grained oolitic grainstone with root traces within the Lower Anhydrite suggests a backshore depositional setting. These backshore deposits could be interpreted as eolianites, which are defined as coastal limestone that records the reworking of vast quantities of shallow-marine biogenic carbonate sediment into coastal dunes. Porosity is mostly interparticle and moldic. The grainstone facies can sometimes be dolomitized in the upper part of high frequency depositional cycles. They are essentially developed in the Upper Arab D, and are abundant in the Arab C, B and A reservoirs. They sometimes occur as thin beds with hummocky cross stratifications in the Marly limestone, and correspond to the deposition of grainstones under storm-driven currents.

G/P: These are the packstone to grainstone facies. Except for the mud content, the elements (grains and fossils) are more or less identical with those of pure grainstones: abundant peloids and ooids, rare intraclasts, green algae, benthic foraminifers, echinoid and bivalve pieces. Sedimentary structures are much less abundant than in the grainstones (few through cross beddings and horse tail structures), but 
bioturbation (mainly Thalassinoides) is much more frequent. They represent facies deposited in shallow moderate energy environment. Packstones rich in green algae and miliolids represent deposits of the backshoal/lagoon environment, whereas muddier packstones rich in bivalves and echinoid debris represent the transition between the coarse sediments of the shoal complex and muddy sediments of the middle to outer ramp setting. Dolomite occurs as sparse small euhedral crystals scattered in the muddy matrix.

P/W: Packstone to wackestone facies. They contain rare peloids, and are rich in pellets, echinoid or bivalve debris, small benthic foraminifers. Few sponge spicules and calcispheres can also be present. Elements are fine grained and well sorted. Due to bioturbation, sedimentary structures are rarely preserved, but some laminations and hummocky cross stratifications are sometimes visible. Horse tail structures and microstylolites are frequent. Bioturbation (mainly Thalassinoides and Chondrites) is particularly abundant, and results in nodular bedding. Bioturbated firmgrounds are numerous. Burrows are generally filled with more grainy sediment. This facies represents low energy oxygenated middle to outer ramp setting. The wackestone/packstone facies are frequently partially dolomitized. Dolomite occurs as sparse small euhedral crystals scattered in the muddy matrix, and/or microsucrosic dolomite replacing the grainy sediment within the burrows. Porosity (mainly micro-porosity) is medium to high and irregularly distributed due to the high bioturbation. $\mathrm{P} / \mathrm{W}$ facies are mostly found in interval DIIIA and DIIIB.

M/W: Mudstone to wackestone facies. They contain no or rare peloids, but are rich in pellets and very small bioclasts: sponge spicules, small benthic foraminifers. A few small echinoid or bivalve debris and calcispheres can also be present. Few laminations are sometimes preserved. Horse tail structures and microstylolites are frequent. Bioturbation (mainly Chondrites) is particularly abundant. This facies represents low energy oxygenated outer ramp setting, below storm wave base for the mudstones. The Mudstone/Wackestone facies are frequently partially dolomitized. Dolomite occurs as sparse small euhedral crystals. Porosity (mainly micro-porosity) is generally low. These facies are essentially developed in the intervals DIIIA and DIIIB.

\subsection{2- Dolomitization of the Arab Formation}

Different models have been proposed for interpreting the dolomitization of carbonate rocks. On the Maydan Mahzam field, the presence of gypsum suggests that dolomitization might be driven by "seepage-reflux". This model requires a periodic flooding of an exposed tidal flat or a sabkha over a limestone. The objective of this diagenetic study is to understand the origin of dolomite in the Arab reservoirs (from top Arab A to Base Arab D) of Maydan Mahzam, and the stratigraphic evolution of the dolomitization processes as well.

Integration of petrographic and stable isotope results has been used to constrain conditions for dolomite formation in the studied samples. Among the different studied samples, four dolomite textures have been identified:

- Fabric-preserving dolomite composed of subhedral and anhedral crystals of $\sim 10-30 \mu \mathrm{m}$ size, rich in inclusions. The original depositional textures of pack- and grainstones are largely recognizable. A sub-type was observed in two samples (MM-25, 7732.5' and MM-29, 7643'), where dolomite crystals have replaced a marine isopachous fringe cement $(\sim 40 \mu \mathrm{m}$ thick $)$ of grainstones. The grains themselves have been dissolved (likely prior to dolomitization), and non fabric-preserving dolomite (see below) has formed partially in the intragranular moldic space. Porosity is inherited from the precursor limestone, with limited additional intercrystalline porosity.

- Fine non fabric-preserving dolomite made of euhedral and subhedral crystals up to $40 \mu \mathrm{m}$ in size, and rich in inclusions. No original textures are visible, although in rare cases grains may have been dissolved, leaving a vuggy texture of the dolomite. At the same time, the dolomite is transitional to the fabric-preserving type. Moderate to good development of intercrystalline porosity is observed.

- Coarse, non fabric-preserving dolomite is characterized by euhedral and subhedral (rarely anhedral) crystals between 40 and $160 \mu \mathrm{m}$ in size. Many crystals contain an inclusion-rich core and a clear overgrowth rim. Original textures are either not visible, or grainy textures are poorly preserved. Intercrystalline porosity is usually well-developed.

- Dolomite cement has been identified on one grainstone sample (MM-25, 7604.6') which has been partly cemented and replaced by euhedral dolomite crystals similar in texture to the coarse, non fabric-preserving type, but with a size of 70$200 \mu \mathrm{m}$. In fact, dolomite crystals encroach on grains. Inclusions in dolomite follow grain outlines, whereas dolomite in intergranular space is clear. Cementation partly reduces intergranular porosity and permeability.

All dolomites are non-luminescent to dull homogeneous red luminescent. In rare cases a slightly brighter red luminescence occurs in the overgrowth dolomite rims. The paragenetic sequence is shown in Figure 3.

Results of the isotopic study are presented in Figure 4. Limestone samples of the Arab-D were analyzed as reference values for un-dolomitized rocks. Their $\delta^{13} \mathrm{C}$ ratio is restricted (2.0-2.4 \%o PDB), with a significant spread of $\delta^{18} \mathrm{O}(-1.9$ to -4 $\%$ PDB).

Isotopic composition of dolomite samples falls into 2 welldefined groups that correspond to distinct petrographic groupings: 
- Group 1: Fabric-preserving and fine non fabricpreserving dolomites have $\delta^{13} \mathrm{C}$ between 2.2 and $3.0 \%$ PDB, and $\delta^{18} \mathrm{O}$ from -1.6 to $-2.7 \%$ PDB;

- Group 2: Coarse non fabric-preserving, dolomite cements and isolated dolomite in limestone have $\delta^{13} \mathrm{C}$ between 2.1 and $3.8 \% \mathrm{PDB}$, and $\delta^{18} \mathrm{O}$ from -4.9 to $-6.7 \%$ PDB

For reference, calcite spar has $\delta^{13} \mathrm{C}$ between 1.2 and $2.8 \%$ $\mathrm{PDB}$, and $\delta^{18} \mathrm{O}$ from -2.4 to $-4.6 \%$ PDB.

The dolomites of group 1 have $\delta^{13} \mathrm{C}$ and $\delta^{18} \mathrm{O}$ close to marine values (Figure 4). The carbon was supplied by inorganic carbonate of the dolomite precursor. The $\delta^{18} \mathrm{O}$ signature likely reflects normal marine or slightly evaporated marine water (Allen \& Wiggins 1993), which is consistent with the stratigraphic context of the dolomites. Estimates of formation temperature, assuming seawater with $\delta^{18} \mathrm{O}=-1$ $\%$ SMOW, yield $\sim 40^{\circ} \mathrm{C}$, which is consistent with such a scenario.

The distinct geochemical and petrographic signature of group 2 dolomites indicates dolomitization from a distinct fluid. Carbon was derived from an inorganic marine precursor. However, the more negative $\delta^{18} \mathrm{O}$ ratio indicates equilibrium with fluids of more negative $\delta^{18} \mathrm{O}$, ie mixed marine-meteoric waters or warmer (burial) fluids (Allen \& Wiggins 1993). The currently available petrographic and geochemical data do not allow a clear distinction between these two hypotheses. Evidence for and against the two hypotheses is discussed below.

A mixing zone dolomite origin would be supported by the moderately negative $\delta^{18} \mathrm{O}$ ratios. The lack of a negative shift in $\delta^{13} \mathrm{C}$, which is usually caused by soil organic carbon, could correspond to an overwhelming dominance of inorganic carbon in the system. On the other hand, there is no stratigraphic relationship between group 2 dolomite samples and any exposure surfaces. Mixing-zone dolomite should be more prevalent in laterally and stratigraphically adjacent to exposure horizons (Badiozamani 1973, Luczaj 2006).

The moderately negative $\delta^{18} \mathrm{O}$ ratios, and the inorganic $\delta^{13} \mathrm{C}$ signature of group 2 dolomites are compatible, but not direct evidence for warm burial fluids (Allen \& Wiggins 1993). In contrast, association of isolated crystals with stylolites in the Arab-D might suggest local formation from compactional fluids supersaturated with respect to dolomite.

In terms of reservoir geometry, group 1 dolomites will correspond to the shallowest part of the platform, where saline dolomitizing brines originated. Areal extent can be on a kilometer to 10's of kilometers scale along dip and strike, but thickness may be limited.

Geometry of group 2 dolomites should vary depending on the interpretation of dolomitization. Mixing-zone dolomites will occur preferentially in zones laterally and stratigraphically adjacent to exposure horizons. In contrast, burial dolomitization could have a much more patchy spatial distribution and geometry. In both cases however, porous and/or undolomitized permeability drains might act as templates for dolomitization. In this respect, the occurrence of two more or less distinct dolomite horizons in coarseningupwards cycles of interval DIIIB is significant. As a first hypothesis, dolomitizing fluids may have been channelled through thin granular beds and could have formed group 2 dolomites (Lindsay et al. 2008).

\subsection{3- Depositional Environments}

For the Arab D reservoir, the inner ramp is represented by a sabkha and a tidal flat where algal mats are developed (Figure 5). The deposition of washover grainstone facies are locally observed on both algal mats and sabkha environments. The middle ramp shows the development of lagoonal facies, which include both low and high energy facies. The deposition of wackestone takes place in quiet and restricted areas, while grainstones/packstones are deposited in higher energy settings, as for example close to tidal channels and at the vicinity of the tidal flat (shallow water depth). The lagoon is also characterized by the deposition of rudstones, which are transported and accumulated in tidal channels. A bioclastic shoal is developed in front of the lagoon. This shoal, defined as a shallow water environment under high energy conditions, is represented by the deposition of rudstones and grainstones mainly composed of Cladocoropsis fragments. The foreshoal marks the transition with the outer ramp depositional system, where Cladocoropsis buildups are documented. The outer ramp is characterized by low energy environments. The proximal part of the outer ramp is dominated by the deposition of packstone with peloids and bioclasts. The packstones are often strongly bioturbated (Thalassinoides-dominated burrows). The distal outer ramp is characterized by the deposition of packstones and wackestones. Vertical burrows appear dominant on the upper part of the distal outer ramp, the lower part being dominated by horizontal burrows. The offshore represents the deeper depositional environment of the Arab D reservoir, where mudstones are mainly deposited.

The depositional model proposed for the Arab A, B, and C reservoirs is consistent with the large scale progradation of these intervals (Figure 5). This model is characterized by a high-energy shoal, a sabkha with dominant microbial flats and stromatolites, and an evaporitic zone. The sabkha corresponds to an area where stromatolites are developed. Their growth suggests some episodic flooding of the embayment, due to a combined effect of tide, storms, and water capillarity flooding. The stromatolites systematically occurred at the top of the Arab C, B and A reservoir depositional sequences. The highest energy facies are represented by cross-bedded oolitic grainstones and packstones that formed a shoal complex and which represent the best reservoir quality rocks of the Arab-D. 


\section{2- Sequence Stratigraphy Model}

The sequence stratigraphic analysis performed during this study highlights three long term depositional sequences for the Arab D reservoir, equivalent to " 3 rd order sequences" sensu Vail et al. (1977). Concerning the Arab A, B and C, each reservoir interval can be subdivided into several 4th order sequences. The general sequence stratigraphy model established during this project is presented in Figure 6.

Interval Arab DIIIB is organized in three depositional cycles. A shallowing-up cycle is developed from the base of the Arab D reservoir, and dolomitization is developed at the top of this cycle. Above, a deepening-up cycle starts with the deposition of packstones and grainstones which shows a strong reworking by storm-driven currents (presence of hummocky-cross stratifications). The top of this cycle is marked by a hard-ground in cores. A shallowing-up cycle occurs at the upper part of interval DIIIB, which shows a general coarsening upward trend that indicates a general progradation of coarser bioclastic sediment. The top of interval DIIIB is limited by an erosive surface (sequence boundary).

The intervals Arab DIIIA to DI form the second long term depositional sequence. The transgressive part of this cycle corresponds to the deposition of Interval Arab DIIIA, composed of stacked burrowed wackestone to packstone facies deposited in a low energy outer shelf environment. The top of this transgressive cycle is marked by a hard-ground corresponding to a maximum flooding surface.

Interval DII and DI represent a shoaling complex, lagoon and sabkha environments, and therefore represent the progradation of the carbonate ramp. Interval DIIC is generally composed of low energy facies at the base which grade upward into high energy coarse grain facies deposited on the shoal. Cladocoropsis reefs may also occur during this interval. Interval DIIB shows an important dolomitization at its top. This interval exhibits facies from intertidal settings to foreshoal Cladocoropsis reefs. Interval DIIA is represented by a shallowing-upwards cycle with dolomitized high energy facies. The shallower facies are composed of algal mats. The uppermost few feet of Interval DI are composed of burrowed dolomitic wackestone with some frequent very coarse erosional rudstone at the base, corresponding to transgressive lag deposits. This significant flooding event is observed on all cored wells and corresponds to the transition before the deposition of anhydrite at the base of the Arab $\mathrm{C}$ reservoir. The basal erosional surface is therefore interpreted as a sequence boundary at the base of the 3rd order cycle.

The Arab $\mathrm{C}$ is subdivided into three $4^{\text {th }}$ order cycles. An important deepening-up event is characterized by the deposition of limestone. The Arab B is subdivided into two $4^{\text {th }}$ order cycles, dominated by the deposition of anhydrite, and intertidal to supratidal dolomitic limestone. The dolomitic facies includes stromatolite deposits. The Arab $\mathrm{A}$ is subdivided into three $4^{\text {th }}$ order cycles characterized by the deposition of anhydrite, intertidal and supratidal dolomitic limestone, and stromatolite facies at the top.

\section{3- Paleogeography}

For this study, paleogeographic maps are used as trends in order to constrain the geostatistical propagation of the electrofacies in the 3D grid. For the overall Arab Formation, these trend maps reflect the 2D distribution of the depositional environments and their stratigraphic variations through the different reservoir intervals. The construction of these paleogeographic maps is mainly based on the interpretation of the depositional environments derived from core description, and also integrates the depositional thicknesses observed at each reservoir interval, which help to define regional prograding trends.

For the Arab D reservoir, six paleogeographic maps have been constructed (Arab DIIIB, DIIIA, DIIC, DIIB, DIIA, DI). They show the distribution of the burrowed depositional environments within intervals DIIIB and DIIIA, and characterize the stepwise progradation of the middle (shoal) to inner ramp (sabkha) facies from DIIC to DI. Shoal reservoir facies are interpreted as to be deposited along a narrow facies belt, that can appear laterally disconnected due to the intercalation of a foreshoal environment (as seen in DIIA). The maps are shown in Figure 7.

A quality check of these paleogeographical reconstructions has been performed by using porosity and lithological data coming from a seismic characterization study. It is demonstrated that a good correspondence is observed between the distribution of the depositional environments and the average porosity map of interval DII. This integration has been be of great help to guide the geostatistical propagation of the log pre-rock types in the $3 \mathrm{D}$ geological grid, and to predict reservoir facies occurrence as well where no well data are available.

Also, 3D illustrations of the Arab Formation paleogeography have been performed, based on the stacking of the successive 2D maps. An example is given for the Arab $\mathrm{D}$ reservoir in Figure 8. This 3D block illustrates the sequence architecture of the Arab D carbonate platform in response to accommodation variations. This diagram has been used to define "dummy" vertical proportion curves in order to better constrain the propagation of rock types in the $3 \mathrm{D}$ geological model.

\section{4- Rock Typing}

Rock types have been defined thanks to the integration of geological, petrophysical and dynamic data at different scales, which includes cores, thin section, sedimentological models, sequence stratigraphy and paleogeographic maps, logs, CCAL and SCAL measurements. The workflow is illustrated in Figure 2.

As a first step, core pre-rock types have been defined based on observations from cores and thin section on five key cored wells. The different intervals of the Arab formation have been studied by groups, which were based on the 
sequence Stratigraphy analysis and on sedimentary facies. Four groups have been defined:

- Arab A + Arab B, in which five pre-rock types have been defined;

- Arab C, in which 12 pre-rock types have been defined;

- Arab D (from DI to DIIIA), in which 13 pre-rock types have been defined;

- Arab DIIIB, in which 11 pre-rock types have been defined.

At the scale of the whole Arab formation, 27 different core pre-rock types have been defined and are summarized in Table 1. Conventional core analysis (porosity, permeability and density) and log signatures (Gamma Ray, Neutron and Density) have been integrated for the differentiation of petrophysical classes. We observed that the stratigraphic distribution of the core pre-rock types is strongly controlled by their location within the depositional sequences defined along the overall Arab Formation. An example is given in Figure 9.

\begin{tabular}{|c|c|c|c|c|c|}
\hline RT & Description & core/log preRT & $A+B$ & C & D \\
\hline \multirow{2}{*}{1} & \multirow{2}{*}{ tight limestone \& anhydritic dolomite } & 1 & & & $\mathrm{x}$ \\
\hline & & 2 & $\mathrm{x}$ & $x$ & $\bar{x}$ \\
\hline 2 & nodular anhydritic dolomite & 3 & $\bar{x}$ & $\mathrm{x}$ & \\
\hline 3 & microporous dolomite/dololimestone & 4 & & & $\mathrm{x}$ \\
\hline 4 & microporous dololimestone (moderate) & 7 & & & $\mathrm{x}$ \\
\hline 5 & microporous dololimestone (good) & 8 & & $x$ & $\mathrm{x}$ \\
\hline 6 & microporous limestone ( $\mathrm{M}$ to $\mathrm{W}$ ) & 9 & & & $\bar{x}$ \\
\hline 7 & microporous limestone (W to P) & 10 & & & $\mathrm{x}$ \\
\hline 8 & microporous limestone (P to $\mathrm{G}$ ) & 11 & & & $\bar{x}$ \\
\hline 9 & intergranular to moldic limestone $(\mathrm{G})$ & 12 & & $x$ & \\
\hline 10 & intergranular limestone $(\mathrm{G})$ & 13 & $x$ & & \\
\hline 11 & intergranular limestone ( $\mathrm{G}$ to $\mathrm{R}$ ) & 14 & & $x$ & \\
\hline \multirow{2}{*}{12} & \multirow{2}{*}{ enlarged intergranular limestone ( $R$ to $B$ ) } & 15 & & & $x$ \\
\hline & & 15.5 & & & $x$ \\
\hline 13 & vuggy and enlarged intergranular limestone & 16 & & & $x$ \\
\hline 14 & intergranular to moldic limestone $(\mathrm{G})$ & 17 & & & $\bar{x}$ \\
\hline 15 & vuggy/moldic dololimestone (W to G) & 18 & & $x$ & $\bar{x}$ \\
\hline 16 & microporous dololimestone (poor) & 19 & & & $x$ \\
\hline 17 & vuggy dolomite & 20 & $x$ & $\mathrm{x}$ & \\
\hline \multirow{2}{*}{18} & \multirow{2}{*}{ microporous dolomite $(\mathrm{G}+\mathrm{B})$} & 21 & & & $x$ \\
\hline & & 22 & & & $x$ \\
\hline \multirow{2}{*}{19} & \multirow{2}{*}{ intergranular to moldic microsucrosic dolomite } & 23 & & $x$ & $\mathrm{x}$ \\
\hline & & 24 & & $x$ & $\mathrm{x}$ \\
\hline \multirow{2}{*}{20} & \multirow{2}{*}{ moldic to intergranular dolomite } & 25 & $x$ & $x$ & \\
\hline & & 26 & & $x$ & \\
\hline 21 & intergranular lithoclastic dolomitic rudstone & 27 & & $x$ & \\
\hline
\end{tabular}

Table 1: Definition of rock types (RT). The location of rock types within each group is indicated by $X$ ( $A+B$ : Arab $A$ and Arab B, C: Arab C, D: Arab D).

The log pre-rock types are defined from logs and must correspond to core pre-rock types. Being defined from logs, they can be calculated along all cored and uncored wells. This has been successfully done with a statistical clustering method, which gives a full control on the electrofacies definition process and allows getting the best possible quality $\log$ in pre-rock type definition.

The log pre-rock types have been calibrated along the five key cored wells used for the definition of the core pre-rock types. By reference to the original database, two sets of logs have been used during the calibration of the log pre-rock types: NPHI+RHOB+DT and NPHI+RHOB+PEF.

- NPHI, RHOB, DT for Arab A, Arab B, Arab C, Arab DI to Arab DIIIA;

- $\quad$ NPHI, RHOB, PEF for Arab DIIIB.

As some wells have NPHI-RHOB-DT and others have $\mathrm{NPHI}+\mathrm{RHOB}+\mathrm{PEF}$, it has been necessary to calculate log prerock types with NPHI+RHOB+PEF from Arab A to Arab DIIIA, and with NPHI+RHOB+DT in Arab DIIIB, in order to be able to populate all the wells with log pre-rock types. A quality check of the log pre-rock type prediction robustness has been performed with regard to the two sets of logs, on four wells which have the four logs $\mathrm{NPHI}+\mathrm{RHOB}+\mathrm{DT}+\mathrm{PEF}$. RT distribution and frequency were consistent with the ones obtained from the two sets of logs.

After the validation of the extension to all the cored wells, the extension to all the uncored intervals was performed.

The understanding of the location of pre-rock types along a depositional profile is crucial for the geostatistical modeling, allowing the improvement of the prediction of pre-rock types in areas devoid of wells. Also, this step has contributed to merging some of the log pre-rock types for the definition of the final reservoir rock types.

For this purpose, the exercise has been performed on cored wells only for which the depositional environments have been clearly identified during the sedimentological study, and for which the log pre-rock types have been already defined. The correspondence of both information evidences some specific stratigraphic occurrences of log pre-rock types. For example, log pre-rock types 15 and 15.5, interpreted as related to shoal environments, are mainly abundant in interval DII. Other log pre-core types showing poor reservoir quality (log pre-rock type 1) are in agreement with a specific occurrence in interval DIIIB, corresponding to the deposition of mud-dominated facies in the deepest depositional environments (offshore settings). The relationships between core/log pre-rock types and depositional environments are illustrated on Figure 10.

The blind-tests, corresponding to Step 3 in the workflow (Figure 2), were performed on cored wells which have not been used for defining the core pre-rock types. Core pre-rock types have been defined on these new wells through the overall Arab Formation, and compared with the log pre-rock types defined during the extension to all the wells. We observed a good correlation between core pre-rock types and predicted log pre-rock types. Some discrepancies are mainly due to the difference of resolution between logs and thinsections, or to locally altered log responses. In general, this work led to an enhancement of the log pre-rock type prediction process in some intervals and to update all the wells.

At step 4, the final rock types were defined after the blind tests by merging adjusted log pre-rock types, when possible. 
This merging has been made just before the extension in the 3D geological grid. Pre-rock types have been merged only if they have similar texture, similar petrophysical properties (same location in the $\mathrm{Phi} / \mathrm{K}$ plot), if they are in the same depositional environment and at the same place in the stratigraphic sequence, and if they have similar $\mathrm{Pc}$ and $\mathrm{Kr}$ curves.

The final correspondence table between log pre-rock types and rock types is shown in Table 1.

\section{5- 3D static modeling}

A geological 3D grid was populated with static properties including rock types, porosity and permeability. The spatial distribution of rock types was calculated using the SIS method in Petrel ${ }^{\odot}$. Truncated Gaussian methods could have been used, but these techniques imply a strict ranking of rock types and restrictions on the possible contacts between them, which is not consistent with our observations and geological interpretations.

In Maydan Mahzam field, significant lateral variations in rock-type distribution must be expected, which requires constraining the geostatistical algorithms with trends. In Petrel $^{\odot}$ software, trends can be defined by using a 3D block of probability for each rock type. This option has been used as it provides a better and a stronger control on the result, and allows taking into account varying trends in a given lithostratigraphic unit.

The most efficient way for building such a block consists of calculating several local vertical proportion curves from well groups and interpolating rock type proportions in the $3 \mathrm{D}$ geological grid from these vertical proportion curves. The 3D blocks of probability were obtained by calculating local vertical proportion curves from well groups defined on geographic and petrographic criteria. These local vertical proportion curves were calculated in spreadsheets and loaded in Petrel $^{\complement}$ as pseudo-wells.

A total of nine zones defined in Petrel $^{\odot}$ allow determining 9 groups of wells which are used to calculate vertical proportion curves. The vertical proportion curves were computed on the log pre-rock types.

As mentioned previously, an extension of the oil-water contact is observed on the northern part of the Maydan field, far away from the area covered by wells. In order to constrain the propagation of rock types in the full-field model, in particular outside the zone controlled by wells, eleven dummy vertical proportion curves were calculated and introduced in the geological model. These dummy vertical proportion curves were defined according to sedimentological and sequence stratigraphy rules, and were used to control the extrapolations on the northern part of the 3D geological grid (Figure 11)

During this study, local and dummy vertical proportion curves were calculated for all reservoir intervals (Arab A to Arab D). Dummy vertical proportion curves were edited and adjusted for Arab D and C reservoirs, which are characterized by important lateral changes of lithofacies and rock types. Regarding Arab A and Arab B, the observed good lateral homogeneity of facies and rock types has resulted in duplicating some neighbor vertical proportion curves in order to get dummy vertical proportion curves.

The next step consisted of calculating 3D blocks of proportion (considered as probability of presence) of each log pre-rock type. The calculation of all $3 \mathrm{D}$ proportion blocks integrates the kriging of all VPCs (coming from selected wells in the central part of the grid, and from sedimentological interpretation in the periphery of the grid).

For the interval Arab DI, the log pre-rock-type proportions were distributed in the geological grid using a Sequential Gaussian Simulation (SGS) with the seismic derived dolomite probability map, coming from seismic characterization study, as collocated co-kriging additional constrains.

The consistency between the distribution of the probability of log pre-rock types and geological/sedimentological concepts was carefully checked. Knowing the correspondence between log pre-rock types and the depositional environments (information coming from cored wells), we calculated three probability cubes which are respectively based on the probability of $\log$ pre-rock types from inner ramp, middle ramp, and outer ramp settings. The example shown in Figure 12 illustrates the strong relationship between a high probability (in red on the figure) of "middle ramp" log prerock-types and the development of shoal facies on the paleogeographic map devoted to the top of interval DIIA.

The log pre-rock types defined along the wells and the $3 \mathrm{D}$ blocks of proportion of log pre-rock types were grouped in Rock-Types and in 3D block of proportion of rock types to allow the geostatistical distribution of the rock types in the 3D grid. The rock-types were distributed using the Sequential Indicator Simulation (SIS) method implemented in Petrel ${ }^{\odot}$. This method, which is a geostatistical modeling algorithm, is based on discretized well log data, defined variograms and random seed.

Finally, the resulting 3D blocks of proportion calculated during this study illustrate strong relationships between the probability of rock types and their abundance in specific depositional environments (Figure 13). The final distribution of rock types after the geostatistical simulation closely mimics the heterogeneities in the stratigraphic distribution of the depositional environments coming from the sedimentological study. 


\section{4 - Conclusions}

This paper contributes to the publicly available literature by providing a new sedimentological interpretation of the offshore Arab reservoirs from Qatar. The sequence stratigraphic framework proposed for the Maydan Mahzam field, which includes regional data from the neighboring Bul Hanine field, represents a regional reference to be used and compared for further studies on such reservoirs. Additionally, this study demonstrates that an accurate rock typing combined with the definition of a sequence stratigraphy framework is of prime importance for building 3D static models. Also, this study documents a new methodology for using a non stationary approach in $\mathrm{Petrel}^{\mathcal{O}}$ for the 3D stochastic modeling of rock types.

\section{Acknowledgements}

The authors would like to thank Qatar Petroleum for the permission to publish these results. We are grateful to the multidisciplinary team who was in charge of this integrated reservoir development project.

\section{References}

Al Husseini MI (1997) Jurassic sequence stratigraphy of the western ans southern Arabian Gulf. GeoArabia 2, 361-382.

Allen JR, Wiggins WD (1993) Dolomite reservoirs. AAPG Continuing Education Course Note Series 36.

Ayres MG, Bilal M, Jones RW, Slentz LW, Tartir M, Wilson AO (1982) Hydrocarbon habit in main producing areas, Saudi Arabia. AAPG Bull. 66, 1-9

Badiozamani K (1973) The Dorag dolomitization model-Application to the Middle Ordovician of Wisconsin. Journal of Sedimentary Petrology 43, 965-984.

Handford CR, Cantrell DL, Keith TH (2002) Regional facies relationships and sequence stratigraphy of a super-giant reservoir (Arab-D Member), Saudi Arabia. 22 ${ }^{\text {nd }}$ Annual Gulf Coast Section SEPM Foundation Bob F. Perkins Research Conference, 539-563.

Koepnick RB, Waite LE (1991) Integrated description of the Hadriya and Hanifa reservoirs, Berri Field, Saudi Arabia. Mobil Report Chapter 2, $38 \mathrm{p}$.

Lindsay RF, Cantrell DL, Hughes GW, Keith TH, Mueller HW, Russell SD (2008) Ghawar Arab-D Reservoir: Widespread porosity in shoaling-upward carbonate cycles, Saudi Arabia. GeoArabia 13, 192.

Luczaj JA (2006) Evidence against the Dorag (mixing-zone) model for dolomitization along the Wisconsin arch-A case for hydrothermal diagenesis. AAPG Bull. 90, 1719-1738.

Murris RJ (1980) Middle East stratigraphic evolution and oil habitat. AAPG Bull. 4, 597-618.
Scotese CR (1998) Quick time computer animations, paleomap project. Department of Geology, University of Texas at Arlington.

Vail PR, Mitchum RM, Todd RG, Widmier JM, Thompson S, Sangree JB, Bubb JN, Hatleilid WG (1977) Seismic stratigraphy and global changes of sea level. In: C.E. Payton (Editor), Seismic Stratigraphy-Applications to Hydrocarbon Exploration. AAPG Mem. 26, 49-212.

Petrel $^{\odot}$ is a trademark of Schlumberger 


\section{Figures}

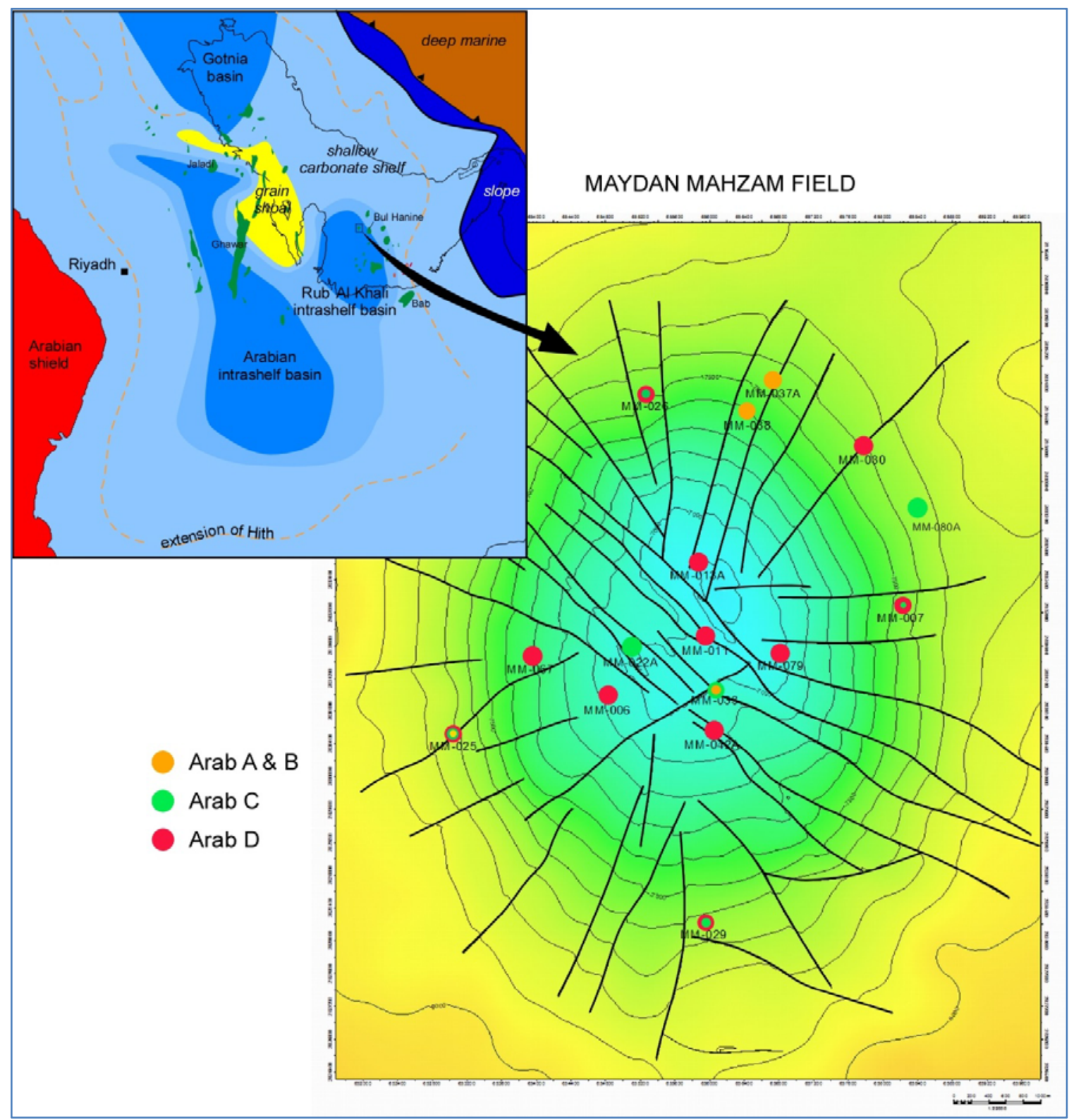

Figure 1: Paleogeography at the Kimmeridgian times and Top Arab D structure map of the Maydan Mahzam field. Paleogeography is compiled from Al Husseini (1997), Ayres et al. (1982), Handford et al. (2002), Koepnick and Waite (1991), Murris (1980) and Scotese (1998). 


\section{properties}

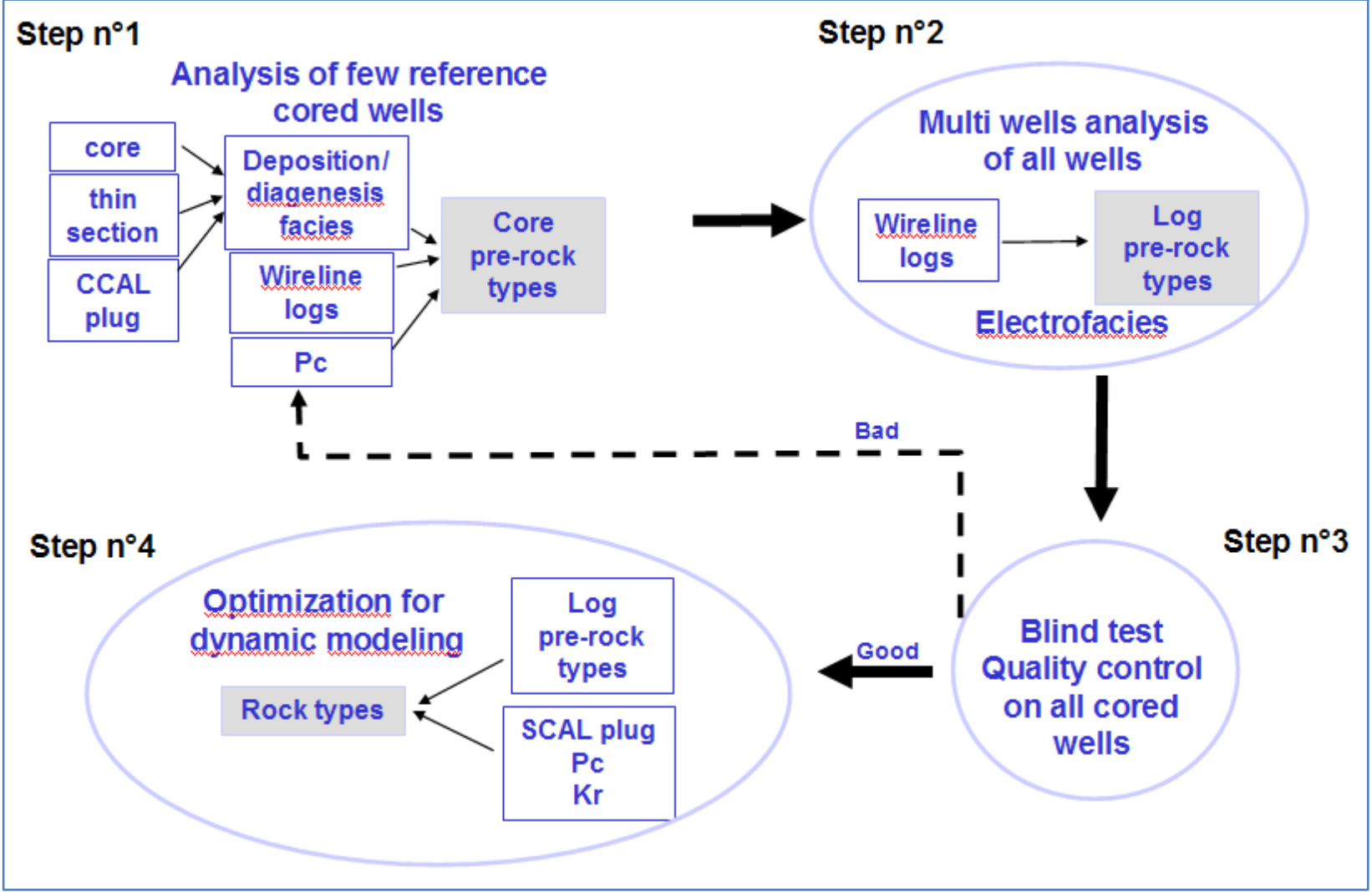

Figure 2: Workflow for the definition of rock types

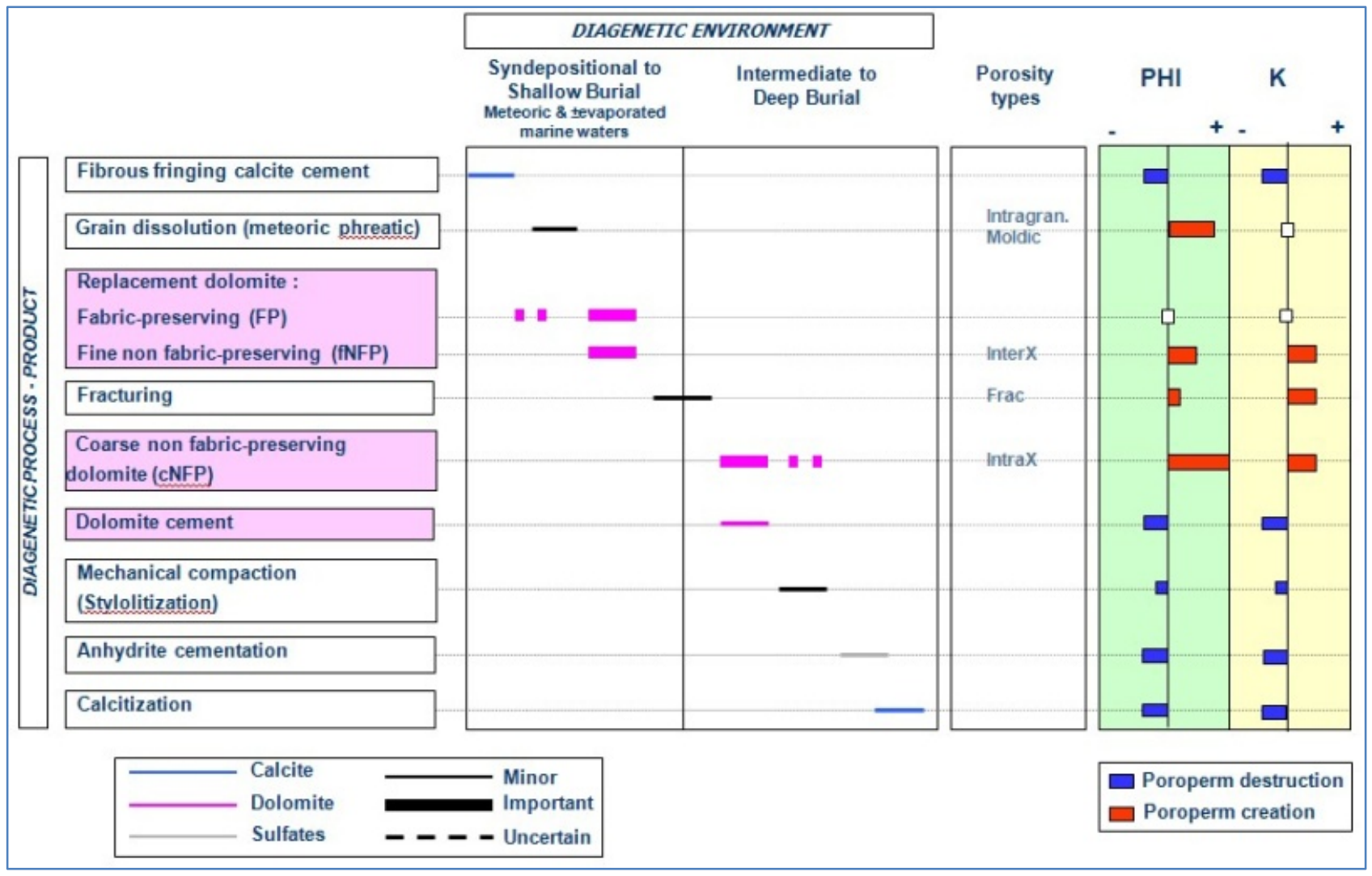

Figure 3: Diagenetic sequences and impact on petrophysical 


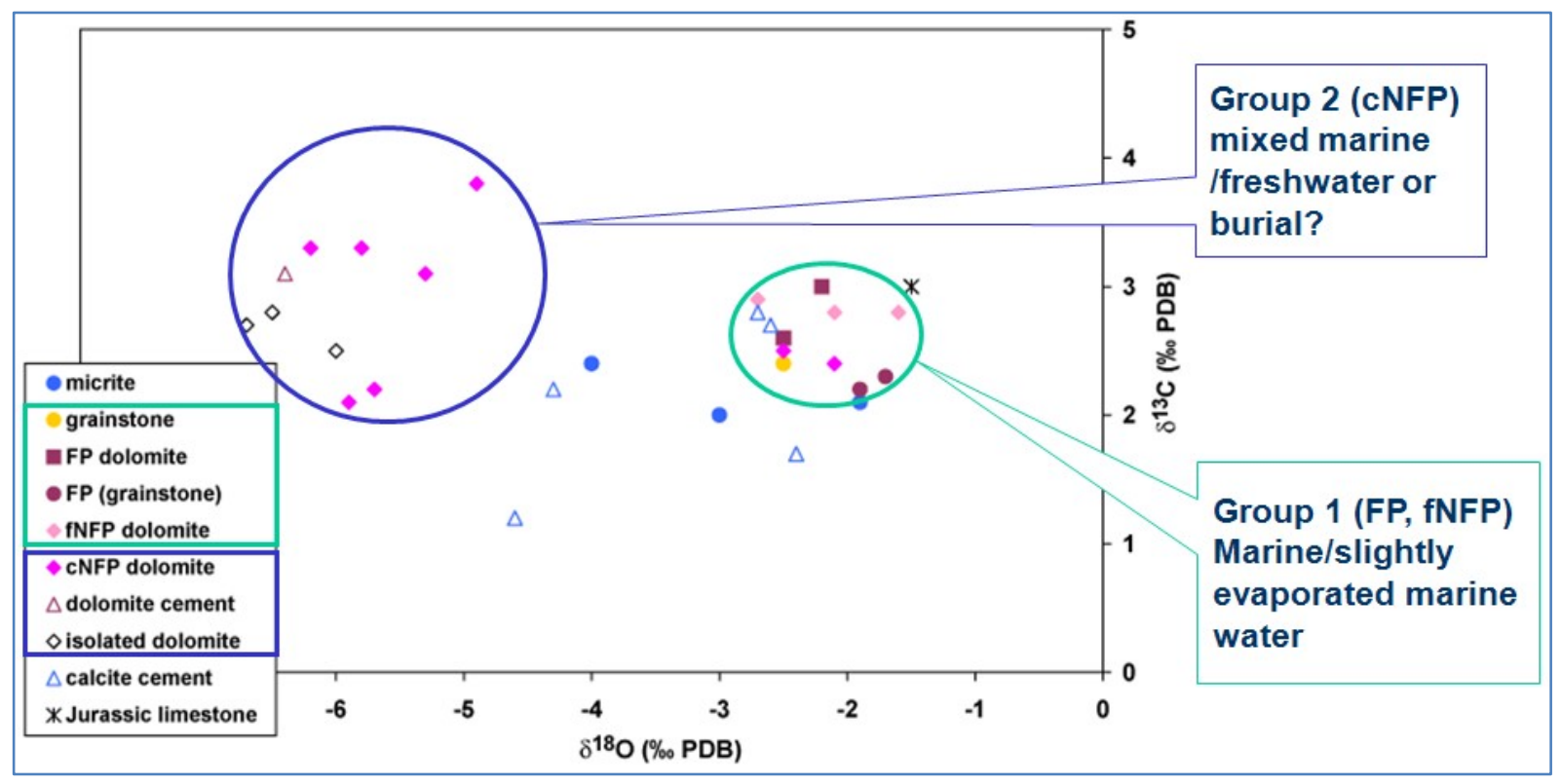

Figure 4: Result of the isotopic study focused on dolomitic samples of Maydan Mahzam field

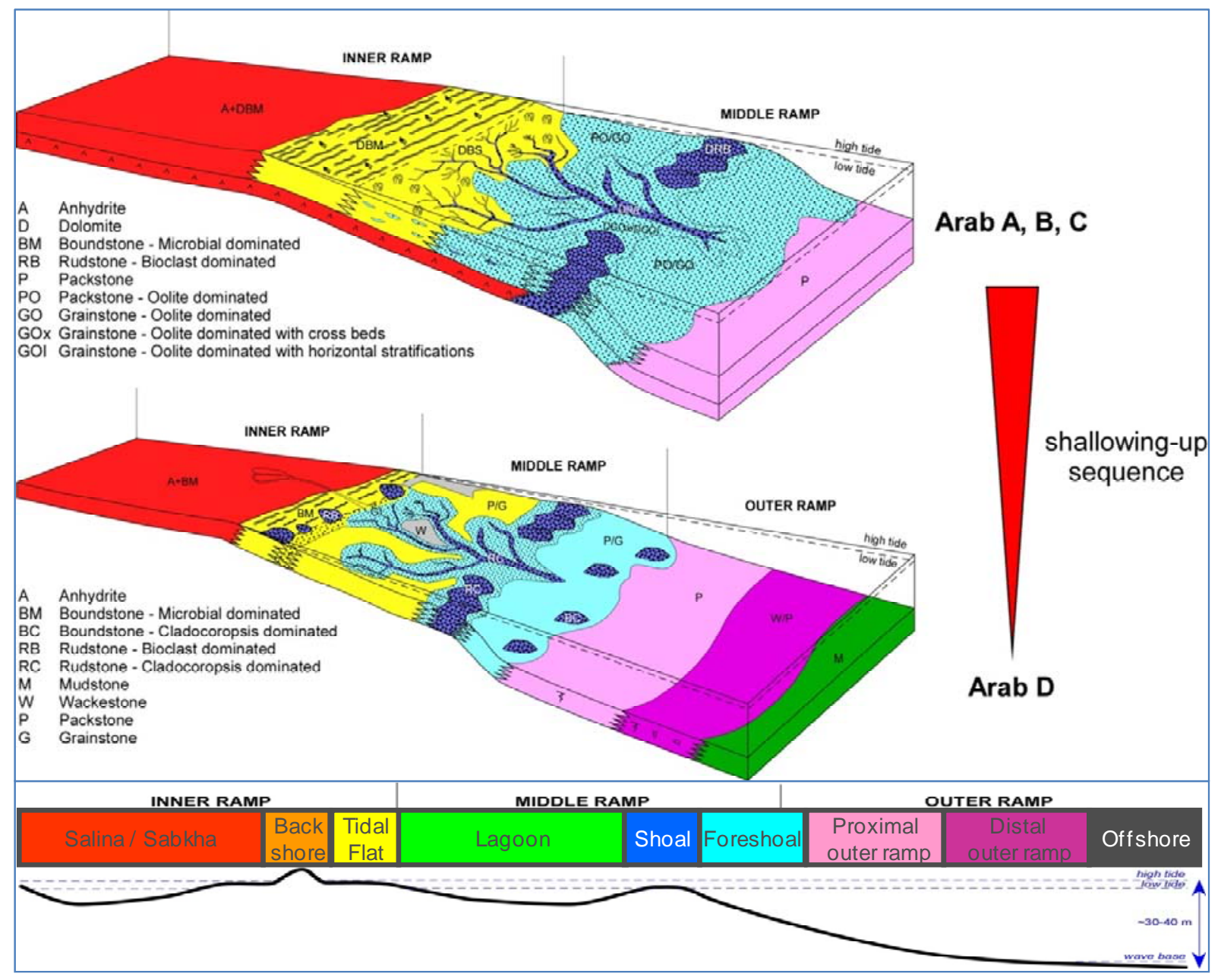

Figure 5: Schematic 3D distribution of facies belts for Arab reservoirs illustrating a major shallowing-up sequence. 


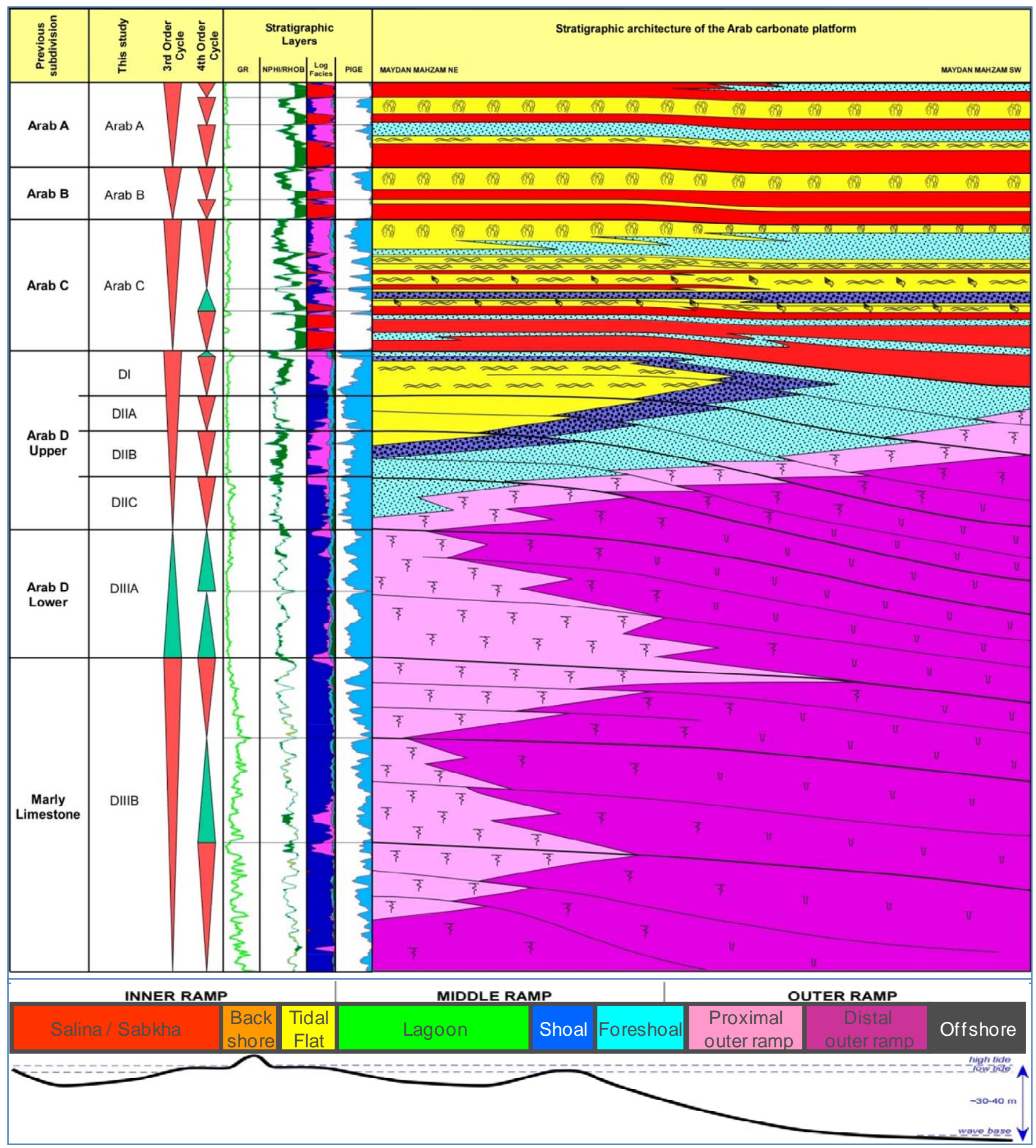

Figure 6: Sequence stratigraphy model of Maydan Mahzam field 


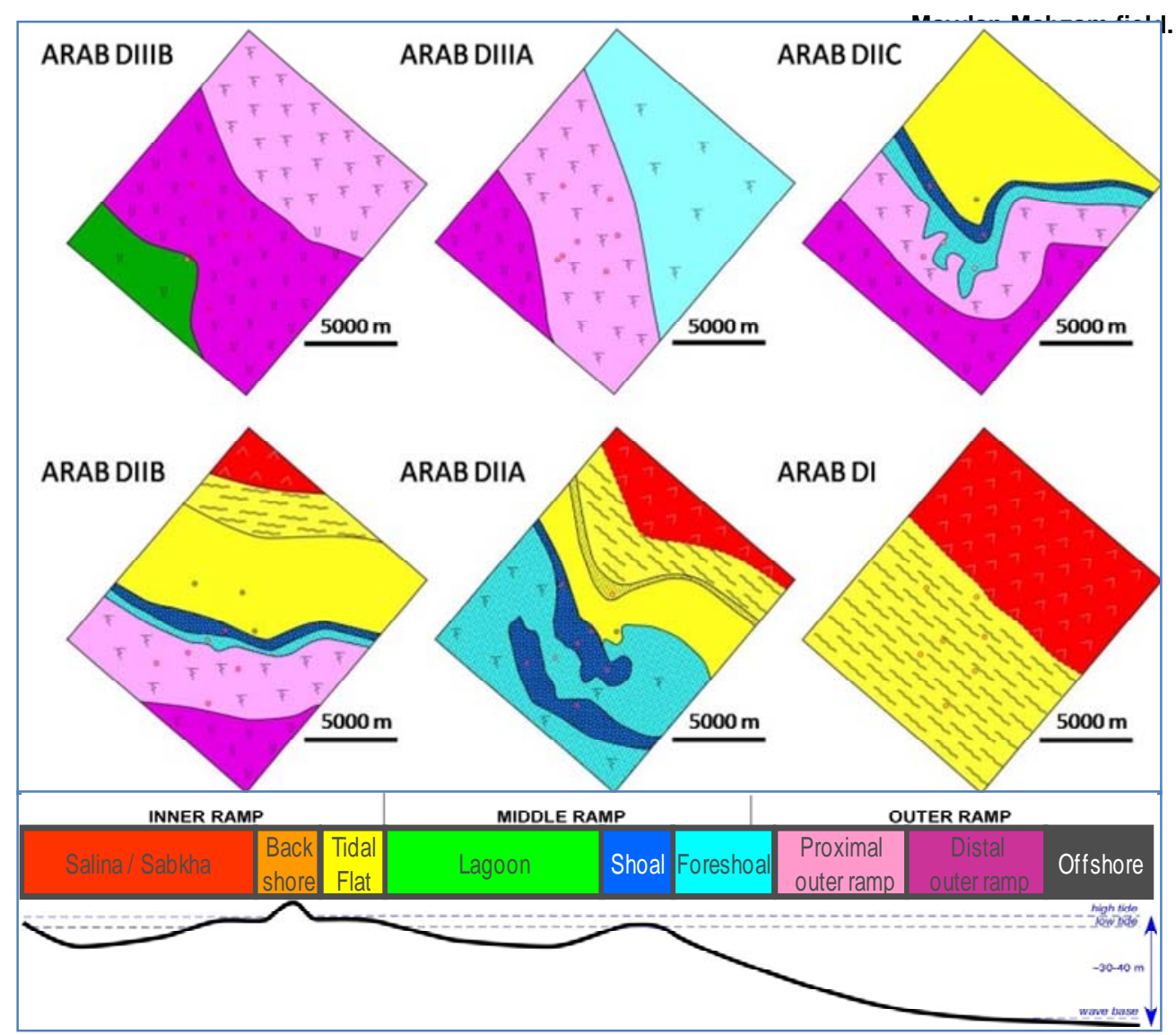

Figure 7: Paleogeographic maps of the Arab D Formation, Maydan Mahzam field

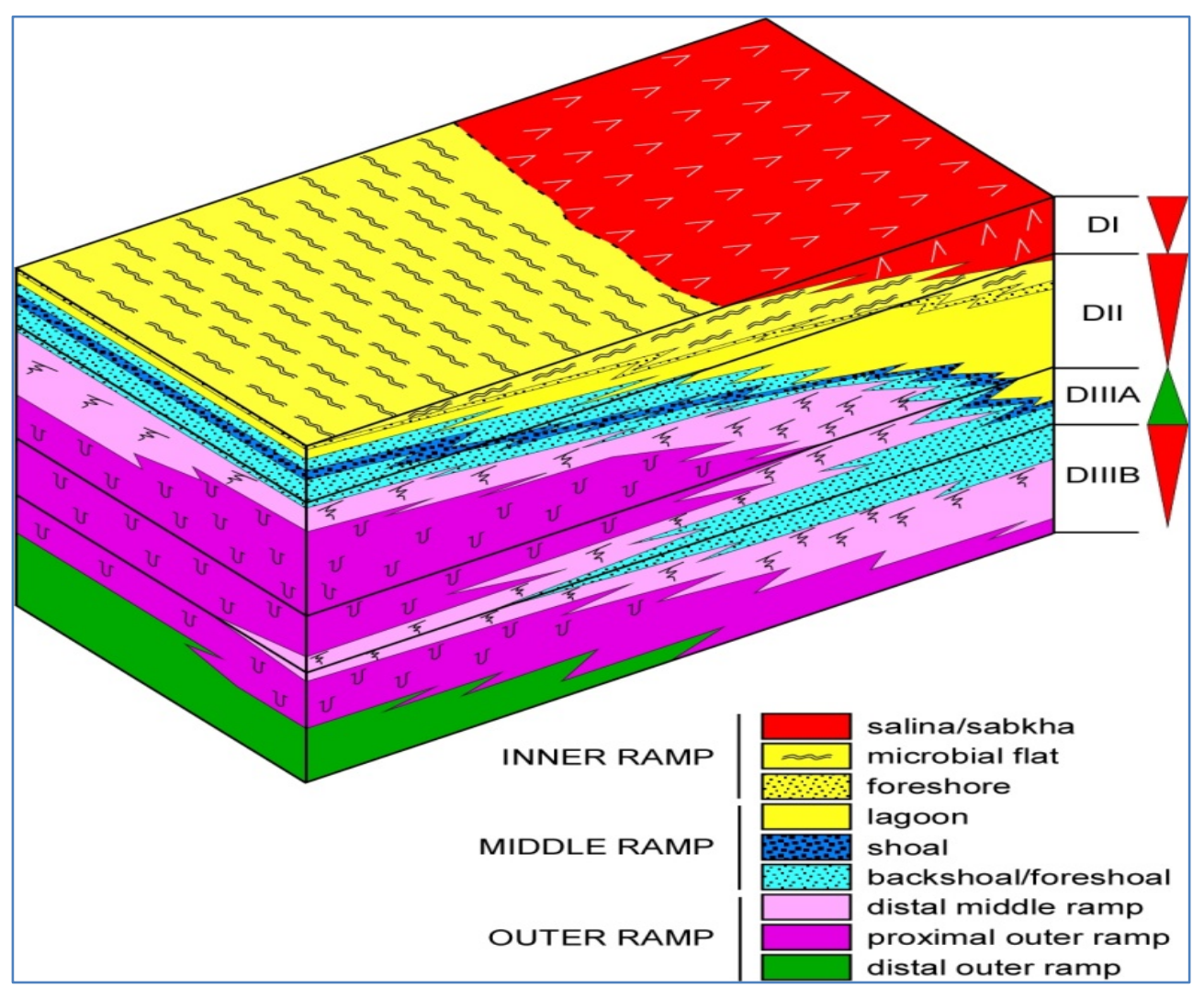

Figure 8: 3D schematic diagram showing the internal stratigraphic architecture of the Late Jurassic Arab D carbonate platform, 


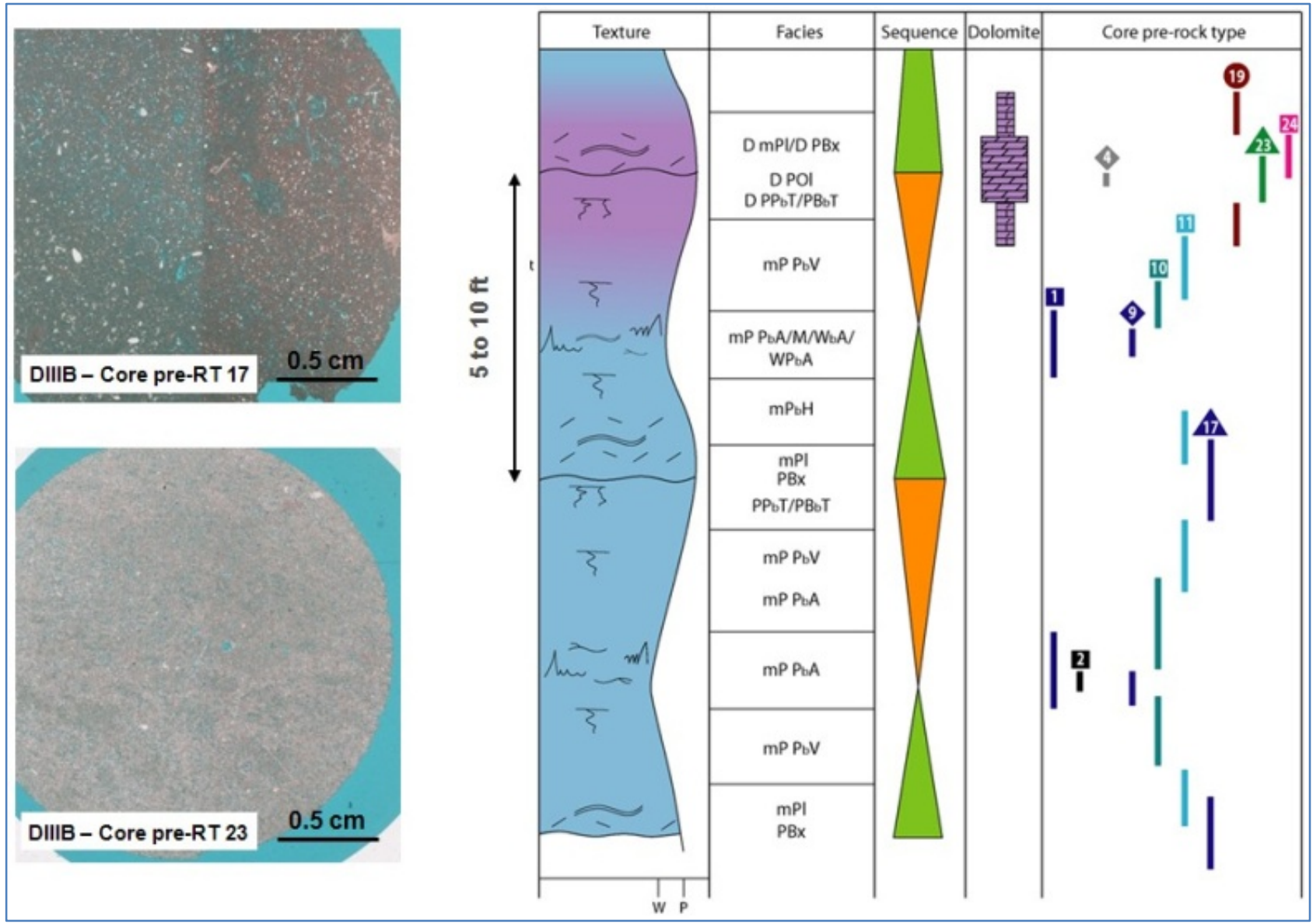

Figure 9: Stratigraphic control on the vertical distribution of core pre-rock types for interval Arab DIIIB.

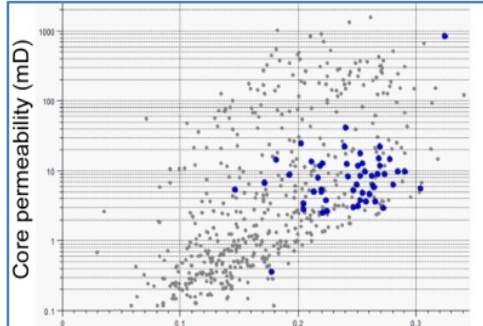

Core porosity $(\%)$

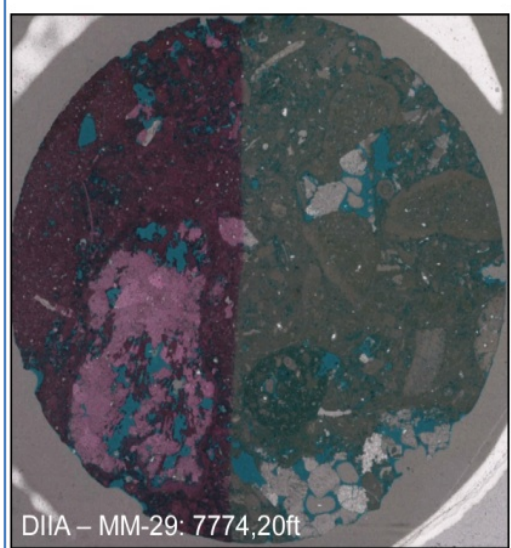

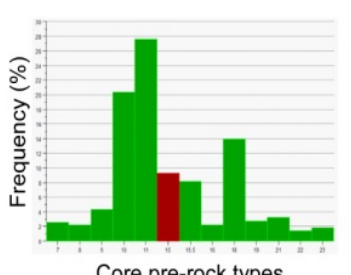

Core pre-rock types

Distribution of core/log pre-rock types on depositional profile

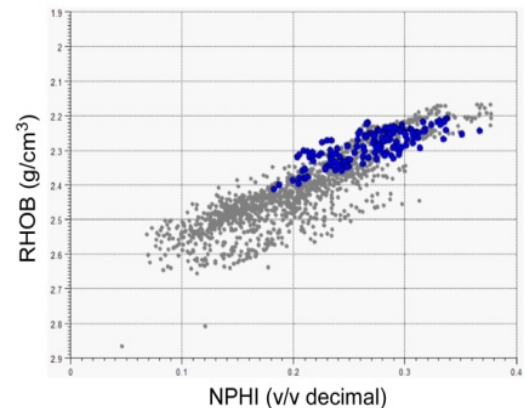

Log pre-rock types
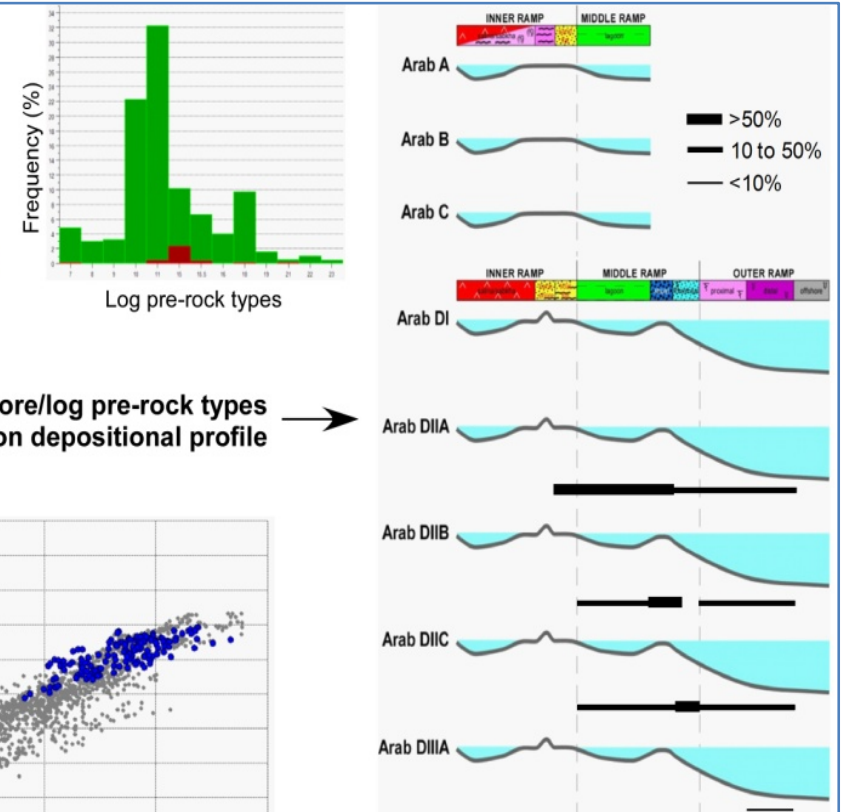

Arab DIIIB

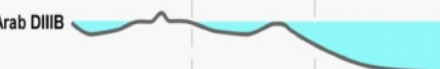

Figure 10: Definition of core and log pre-rock type 15.5 and relationships with stratigraphy and depositional environments. 


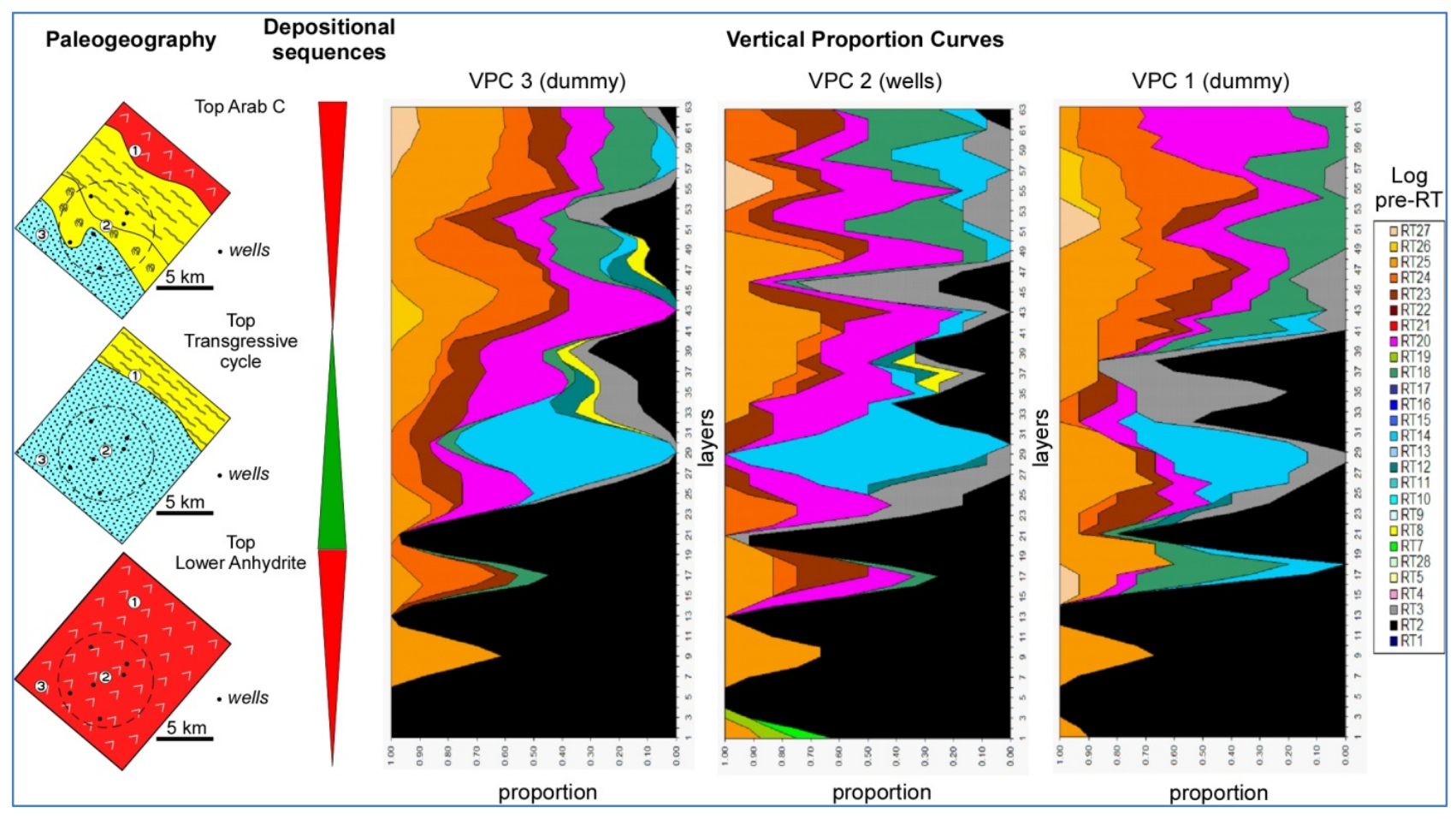

Figure 11: Example of edition of vertical proportion curve in the Arab $\mathrm{C}$ reservoir. The dashed circle on the paleogeographic maps represents the zone controlled by wells. The edition of VPC outside of this zone is due to the northward extension of the oilwater contact.

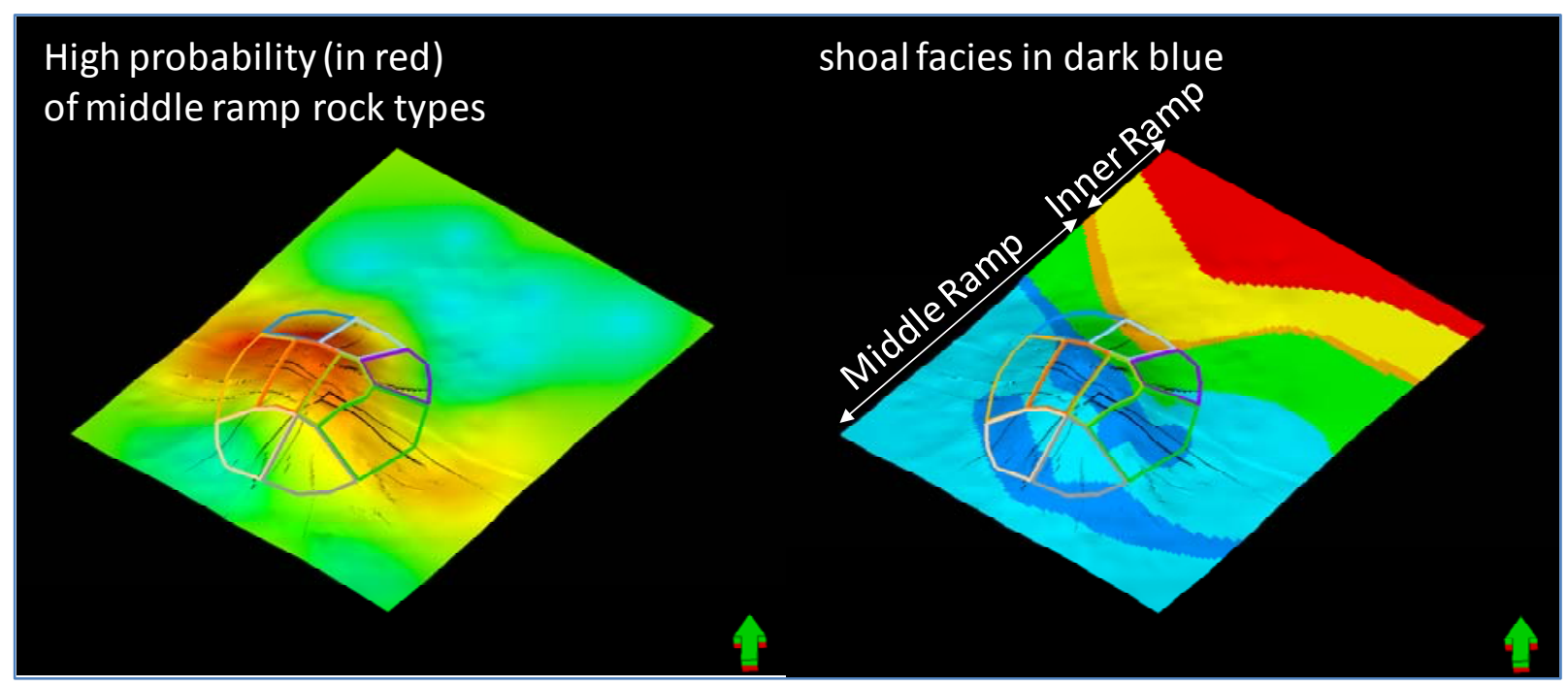

Figure 12: Correspondence between probabilities of log pre-rock type 15.5 (Cladocoropsis-dominated rudstone) and the paleogeographic map of Interval Arab DIIA. The shape of the shoaling facies is clearly reproduced in the 3D block of proportion that is used to constrain the propagation of this rock type in the 3D geological grid. 


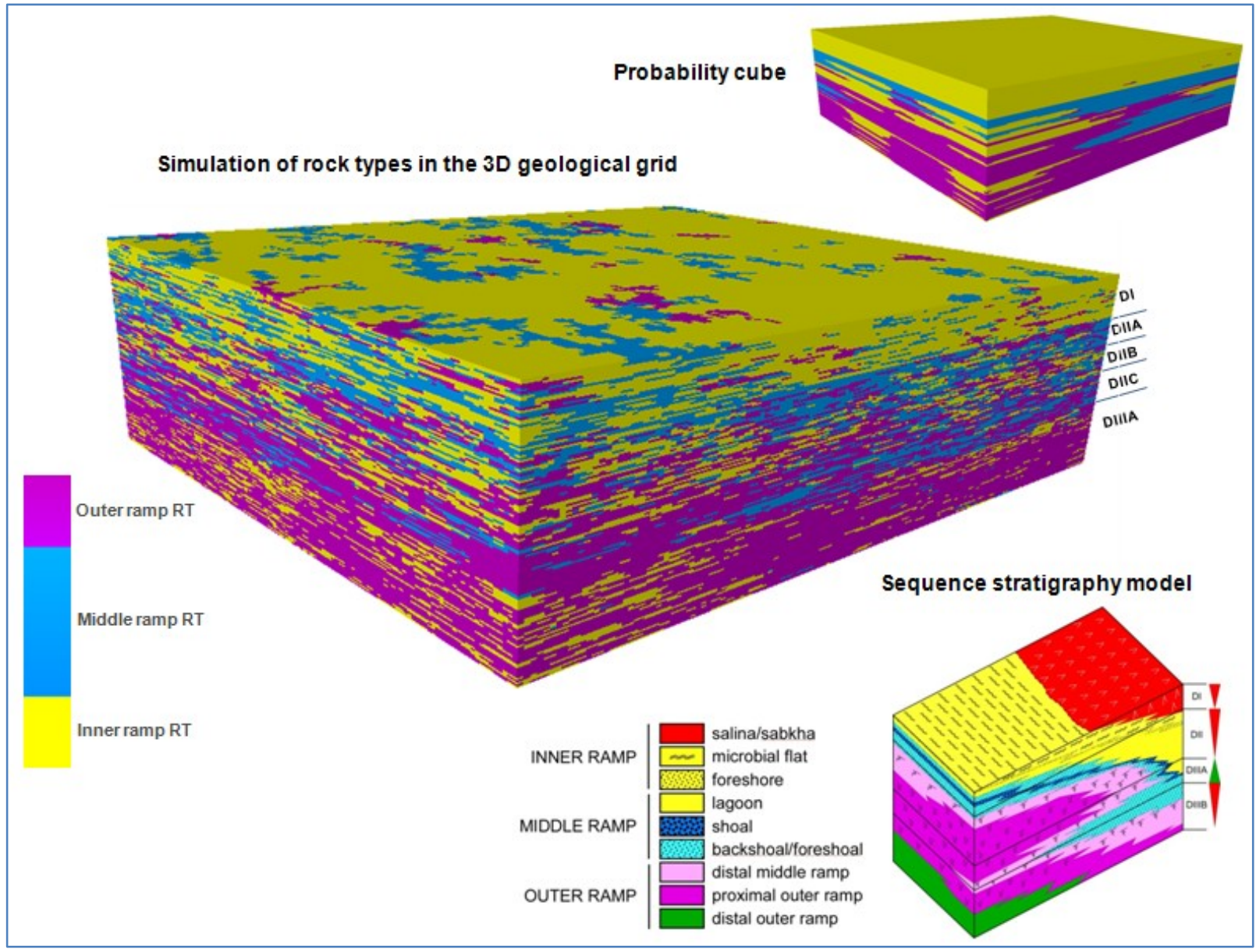

Figure 13: Overview of the rock type's distribution for the interval Arab DIIIA-DI. The rock types have been grouped according to their attribution to depositional environments. For this study, the geostatistical simulation was constrained by 3D probability cubes, which are derived from the kriging of vertical proportion curves. 